\title{
COVID-19: Uncertainties from Conception to Birth
}

\section{Covid-19: incertezas desde a concepção até o nascimento}

\author{
Bruno Ramalho de Carvalho ${ }^{1}$ Karina de Sá Adami ${ }^{20}$ Walusa Assad Gonçalves-Ferri \\ Marise Samama ${ }^{4}$ Rui Alberto Ferriani ${ }^{5 \odot}$ Alessandra Cristina Marcolin ${ }^{5(0)}$ \\ ${ }^{1}$ Hospital Sírio-Libanês, Brasília, DF, Brazil \\ 2 Maternidade Climério de Oliveira, Universidade Federal da Bahia, \\ Salvador, BA, Brazil \\ ${ }^{3}$ Department of Pediatrics, Faculdade de Medicina de Ribeirão Preto, \\ Universidade de São Paulo, Ribeirão Preto, SP, Brazil \\ ${ }^{4}$ Department of Gynecology, Escola Paulista de Medicina, \\ Universidade Federal de São Paulo, SP, Brazil \\ ${ }^{5}$ Department of Gynecology and Obstetrics, Faculdade de Medicina de \\ Ribeirão Preto, Universidade de São Paulo, Ribeirão Preto, SP, Brazil \\ Address for correspondence Bruno Ramalho de Carvalho, MD, MSc, \\ SGAS 614, Conjunto C, Sala 177, 70200-740, Edifício VITRIUM - Centro \\ Médico Inteligente, Asa Sul, Brasília, DF, Brazil \\ (e-mail: ramalho.b@gmail.com).
}

Rev Bras Ginecol Obstet 2021;43(1):54-60.
Scientific information on the impact of the new coronavirus (SARS-CoV-2) on the health of pregnant women, fetuses and newborns is considered of limited confidence, lacking good-quality evidence, and drawing biased conclusions. As a matter of fact, the initial impressions that the evolution of COVID-19 was no different between pregnant and non-pregnant women, and that SARS-CoV-2 was not vertically transmitted, are confronted by the documentation of worsening of the disease during pregnancy, poor obstetric outcomes, and the possibility of vertical transmission. The present article aims to compile the data available on the association of COVID-19 and reproductive events, from conception to birth.

As informações científicas sobre o impacto do novo coronavírus, SARS-CoV-2, na saúde de gestantes, fetos e recém-nascidos são consideradas de confiabilidade limitada, sem evidências de boa qualidade, e levam a conclusões enviesadas. De fato, as impressões iniciais de que a evolução da Covid-19 não era diferente entre mulheres grávidas e não grávidas, e de que o SARS-CoV-2 não era transmitido verticalmente, são confrontadas pela documentação de agravamentos da doença durante a gravidez, resultados obstétricos negativos, e a possibilidade de transmissão vertical. Este artigo tem como objetivo compilar os dados disponíveis sobre a associação entre a Covid-19 e os eventos reprodutivos, desde a concepção até o nascimento. received

August 21, 2020

accepted

October 26, 2020
DOI https://doi.org/

$10.1055 / \mathrm{s}-0040-1721856$. ISSN 0100-7203. (c) 2021. Federação Brasileira das Associações de Ginecologia e Obstetrícia. All rights reserved.

This is an open access article published by Thieme under the terms of the Creative Commons Attribution License, permitting unrestricted use, distribution, and reproduction so long as the original work is properly cited. (https://creativecommons.org/licenses/by/4.0/)

Thieme Revinter Publicações Ltda., Rua do Matoso 170, Rio de Janeiro, RJ, CEP 20270-135, Brazil 


\section{Introduction}

In the last 8 months, the world has been experiencing a pandemic caused by the new coronavirus (SARS-CoV-2). Starting with the first reported cases of pneumonia in the city of Wuhan, Hubei province, China, ${ }^{1}$ by August 16, 2020 , 21,294,845 COVID-19 cases had already been confirmed, with a total of 761,779 deaths. $^{2}$ On that date, the Brazilian Ministry of Health had registered 3,340,197 cases of the disease, and 107,852 deaths. ${ }^{3}$

It is a fact that scientific information on the impact of SARSCoV-2 on the health of pregnant women, fetuses and newborns is considered of limited confidence, lacking good-quality evidence, and drawing biased conclusions. As a matter of fact, the initial impressions that the evolution of COVID-19 was no different between pregnant and non-pregnant women, ${ }^{4-6}$ and that SARS-CoV-2 was not vertically transmitted, ${ }^{4,7,8}$ are confronted by the documentation of worsening of the disease during pregnancy, poor obstetric outcomes, ${ }^{9-14}$ and the possibility of vertical transmission. ${ }^{15-20}$

Of note, uncertainty is the rule at the moment. Some state that, then, there are no convincing reasons to recommend people to avoid pregnancy. ${ }^{21}$ In contrast, it seems that there are at least 5 uncertainties/reasons to advise against pregnancy at this time, if it is possible, namely: 1) there is confounding evidence on the evolution of COVID-19 in pregnant and non-pregnant women; 2) despite the fact that the bulk of the literature suggests the effectiveness of the placental barrier in preventing fetal infection by SARSCoV-2, fewreports ${ }^{15,20}$ indicating vertical transmission sustain medical concerns; 3 ) it is not clearly known whether infection by SARS-CoV-2 in the first trimester can cause birth defects or pregnancy loss; 4) it is not known whether the newborns of women infected by SARS-CoV-2 will have the same clinical evolution as those born to healthy mothers; and 5) the possibility of SARS-CoV-2 transmission through the sexual route, and the role of its theoretical effect on the gonads and gametes, in vivo and in vitro.

The present review article aims to compile available data on each of the aforementioned uncertainties, providing theoretical background for counseling and caring for women who are planning a pregnancy, those who are pregnant, or those who have given birth during the COVID-19 pandemic.

\section{SARS-CoV-2 in Reproductive Tissues and Gametes}

The expression of angiotensin-converting enzyme 2 (ACE2) and other viral entry facilitators in male and female gonads and gametes, as well as the endometrium, ${ }^{22-25}$ raises concerns on the interference of SARS-CoV-2 on reproductive health and conception. $^{26}$ To date, it is not known if the new coronavirus affects reproductive function via the ACE2 receptors, and which consequences, if any, the infection by the virus would have on the quality of the gametes, embryo development and implantation, or pregnancy in its very beginning. ${ }^{27}$

Indeed, there are reports of human orchitis related to other coronaviruses. ${ }^{28}$ Then, the possibility of immediate or long-term SARS-CoV-2-related impairment in the male reproductive functions is a genuine concern. Theoretically, inflammation in the seminiferous epithelium, Leydig and Sertoli cells, and the epididymis could lead to oxidative stress and sperm DNA fragmentation, as well as diminished testosterone secretion and disrupted spermatogenesis. ${ }^{29}$

Regarding conception, the possibility of sexual transmission is another matter of concern. SARS-CoV-2 has already been detected in the small intestine, liver, pancreas, kidney and sweat glands, so, at least theoretically, there are other potential routes of transmission than the respiratory one. ${ }^{30}$ The data available on the sexual route of transmission are controversial. In a Chinese cohort study, ${ }^{31}$ SARS-CoV-2 was detected in semen samples from infected patients, both in the acute and in the recovery phases. In contrast, other reports did not find the virus in semen collected 8 days after COVID-19 diagnosis, ${ }^{32}$ or 30 days. $^{33}$ Divergent findings about SARS-CoV-2 in the semen support the need for larger studies, which should not just confirm the presence of the virus in the semen, but provide information about its length of stay and the possibility of transmission by sexual contact.

\section{COVID-19 during Pregnancy}

Maternal and fetal complications were documented in previous epidemics caused by other coronaviruses, namely the severe acute respiratory syndrome (SARS) ${ }^{34}$ and the Middle East respiratory syndrome (MERS). ${ }^{35}$ In addition to historical aspects, physiological adaptations during pregnancy are usually considered to be potential factors of vulnerability to any type of infection. Moreover, some authors suggest that pregnant women are more vulnerable to infective respiratory agents than the general population, and they may respond to COVID-19 with a "cytokine storm," which may lead to severe morbidity. ${ }^{36}$ Beyond this, the signs or symptoms related to pregnancy may overlap with other symptoms of COVID-19, thereby making the diagnosis challenging. So, as a precaution, pregnancy and the puerperium are now considered high-risk situations for severe illness from COVID-19. ${ }^{37,38}$

In June 2020, a systematic review ${ }^{39}$ of 755 pregnant women presenting with COVID-19 provided only poor-quality evidence, and the authors could not rule out potential worsening of the clinical conditions of pregnant women infected with SARS-CoV-2, or whether the infection is associated with comorbidities or not. Actually, the absence of studies with reliable methodology still greatly limits data interpretation. Thus, it cannot yet be said that the disease evolves in the same way in pregnant and non-pregnant women, nor can pregnancy be excluded from the list of potential risk conditions.

In the United States, the Centers for Disease Control and Prevention (CDC) has recently published a series ${ }^{12}$ of 8,207 pregnant women in the United States, associating pregnancy to an increased risk of hospitalization (31.5\% in pregnant women versus $5.8 \%$ in non-pregnant women; adjusted relative risk $[\mathrm{aRR}]=5.4 ; 95 \%$ confidence interval $[95 \% \mathrm{CI}]=5.1$ to 5.6 ), admission to the Intensive Care Unit $(\mathrm{aRR}=1.5 ; 95 \% \mathrm{CI}=1.2$ to 1.8 ), and the need for mechanical ventilation ( $\mathrm{aRR}=1.7 ; 95 \%$ $\mathrm{CI}=1.2$ to 2.4 ) due to COVID-19. Nevertheless, the increase in 
morbidity was not reflected in increased mortality, which was similar between pregnant and non-pregnant women $(0.2 \%$ in both groups; $\mathrm{aRR}=0.9 ; 95 \% \mathrm{CI}=0.5$ to 1.5 ).

Recent data show that most of the women ( 85\%) contracting SARS-CoV-2 will exhibit mild characteristics of the disease. The rates of severe disease vary between $9.3 \%$ and $11.1 \%$, and the rates of critical disease vary between $2 \%$ and $6.9 \%$, which are just as similar to the rates for the general population. ${ }^{40}$ However, local scenarios of care for pregnant women should also be taken into account to better advise the women about the possibility of becoming pregnant. In Brazil, for example, a country with high rates of maternal mortality when compared with developed countries, 124 pregnant or postpartum women have died due to COVID-19 until June 18 , 2020 -representing a mortality rate of $12.7 \%$-, a figure that currently surpasses the total number of COVID-19-related maternal deaths reported throughout the rest of the world. These data suggest an aggravation of the bad preexisting conditions of prenatal care due to COVID-19 infection. ${ }^{10}$

In the context of the COVID-19 pandemic, the high rates of preterm birth, cesarean section, ${ }^{41,42}$ and preeclampsia, ${ }^{43}$ and the increased risk of admissions to the intensive care unit $^{12}$ persist as the most common reasons for concern. Outstandingly, the most frequent COVID-19 adverse obstetric outcome seems to be preterm birth, occurring in $41.1 \%$ (95\%CI: 25.6 to 57.6 ) of cases. ${ }^{42}$ In view of this little-known disease, it is recommended to consider pregnancy a potential aggravating factor for COVID-19, as is customary for other diseases, and, conversely, to consider this infection a cause of negative obstetric and perinatal outcomes. As a precautionary action, it is reasonable to institute unrestricted monitoring measures for pregnant women infected with SARS-CoV2 , and even to suggest that they should be rigorously tested before delivery or before the first contact with the newborns. $^{39}$

\section{Evidence of Vertical Transmission of SARS-CoV-2}

Vertical transmission of previous coronaviruses was hypothesized in preliminary studies, ${ }^{44,45}$ but such an occurrence was not reported with either SARS or MERS; therefore, it seems that the likelihood of intrauterine maternal-fetal transmission of coronaviruses is low. 46,47

To date, it cannot be said that the placental barrier is capable of preventing the vertical transmission of SARS-CoV-2. Often times, tests of the amniotic fluid, cord blood, and neonatal throat swab samples were not able to evidence the vertical transmission of SARS-CoV-2, at least in mid- ${ }^{8}$ and late pregnancy. ${ }^{42,47}$ However, third trimester placentas from COVID-19 patients have been proven to be more likely to present maternal/fetal vascular malperfusion, ${ }^{48}$ and the existence of vertical transmission of SARS-CoV-2 has already been demonstrated in some case reports ${ }^{49,50}$ and small case series. ${ }^{51,52}$ Moreover, the detection of anti-SARS-CoV-2 immunoglobulin $\mathrm{M}$ (IgM) in cord and/or early-life neonatal blood supports the suspicion of intrauterine infection, since IgM is not transplacentally transferred from the mother to the fetus. ${ }^{17}$
Recently, in early July 2020, during one of the virtual sessions of the Annual Meeting of the European Society of Human Reproduction and Embryology (ESHRE), researcher Wafaa Essahib presented evidence of the expression of ACE2 and other viral-entry facilitators in human oocytes and blastocysts, supporting a new hypothesis of transmission of the virus from the mother to the embryo, which would be cause for apprehension for initial pregnancies under COVID-19. ${ }^{53}$ Moreover, the expression of the ACE2 receptor has been reported in the placenta, which may increase the risk of vertical transmission of the virus. $^{54}$

It is worth saying that, if maternal-fetal transmission happens, little is known about its impact over embryogenesis, morphogenesis, fetal development, and health.

\section{The Health of the Fetus and the Newborn}

Initial data suggested that maternal SARS-CoV-2 infection does not seem to be more harmful in the first trimester than it is throughout the whole pregnancy. Infection was not associated with increased thickness of the nuchal translucency or risk of pregnancy loss. ${ }^{55}$ However, other viruses, depending on the gestational age at the moment of infection, have been associated with congenital anomalies and developmental delay later on, like Zika. ${ }^{56}$ Thus, the little time since the first studies on the behavior of SARSCoV-2 is insufficient to evaluate its real impact on neonates.

The RNA of SARS-CoV-2 has already been found in placental and amniotic membrane samples, indicating the possibility of fetal viral exposure during labor and delivery. ${ }^{57}$ Placental infection has also been demonstrated as one of the negative outcomes of pregnancy, not just by identification of viral RNA, but by histological findings of subchorial inflammatory infiltrates, increased intervillous fibrin deposition, and funisitis (suggesting inflammatory response from the fetus $)^{14}$

According to the systematic review of 598 newborns, strong evidence of SARS-CoV-2 infection was not available until June 2020, especially considering the lack of reliable information on the care provided during and after delivery, as well as the lack of adequate collection of biological samples from newborns for the SARS-CoV-2 test. ${ }^{39}$ Indeed, the data available to date suggest that COVID-19 infection is uncommon among newborns, which are frequently asymptomatic. Furthermore, it was not possible to associate a higher risk of infection to vaginal birth, breastfeeding or close contact with the infected mother. ${ }^{58}$

It is worth highlighting the fact that there has been a decrease in extremely premature births during the COVID-19 pandemic. ${ }^{59,60}$ There are still no definite explanations for this unprecedent reduction, but there are two hypotheses: the disease leads to a greater number of early pregnancy losses; or the measures of social distancing and confinement lead to lower exposure of pregnant women to the behavioral and socio-environmental factors linked to prematurity. 


\section{Postponing Pregnancy versus Age-related Fertility Loss}

Since the deleterious effect of postponing pregnancy by a few months may not be significant, ${ }^{61-65}$ even for women of advanced reproductive age or with diminished ovarian reserve, ${ }^{64}$ such a decision has been encouraged by some authors. ${ }^{65,66}$

In a very recent retrospective cohort study on in vitro fertilization treatment for women with diminished ovarian reserves, Romanski et al. ${ }^{65}$ observed that a delay of up to 180 days did not seem to negatively affect live birth rates, even for women with anti-Mullerian hormone levels $<0.5$ $\mathrm{ng} / \mathrm{mL}$, or those older than 40 years of age. The authors recognized a potential selection bias in their study, but considered the results sufficient to reassure that shortterm delay in the treatment will not affect its outcomes, in situations that such a delay is deemed necessary or prudent, like the current COVID-19 pandemic.

For cases of infertility that require assisted reproduction, the dilemmas can be even greater. Advice on whether or not to postpone treatment includes information on the lack of knowledge of the effects of COVID-19 on pregnancy, as well as the possible risks of vertical transmissibility and transmission via the gametes, as well as risks of the virus being stored in the gametes and the embryo. ${ }^{26,66}$ It should be emphasized that the treatment per se lasts several days, and requires several return visits, and, depending on the region's epidemiological situation, it may be inadvisable for patients to move and expose themselves to medical environments. Besides that, the infection can occur during the treatment period, causing suspension at any stage, which can generate significant emotional distress. Finally, the lack of consensus on screening methods contributes to the uncertainty, since the diagnostic tests contain highly-variable sensitivities and specificities, and unfortunately there is no consensus on which one is the best and safest to detect the disease in real time. ${ }^{67}$

\section{Perspectives for the Future}

\section{Pregnancy and Delivery}

At this moment, the best knowledge on COVID-19 in pregnancy is based on observational studies, case series and reports, as well as estimates from the surveillance of sanitary authorities in each country. These provide insufficient information to consider changes in the management and definition of the appropriate interventions. Wise strategies minimizing the risk for the pregnancy and poor obstetric outcomes, mainly those associated to preterm birth, preeclampsia, and cesarean section, will probably be defined once there is wide knowledge of the disease, which will come with time and experience.

There is no doubt that many aspects remain unclear to date, and randomized clinical trials are expected to provide knowledge from preconception counseling and preventive measures during prenatal care to clinical presentation and management of the infection during pregnancy and the puerperium. Oxford-Horrey et al. ${ }^{68}$ opportunely highlight that supportive care must focus on recovery rather than delivery as the main treatment endpoint. Unfortunately, the inclusion of pregnant women in registered trials still seems to be small: among all 3,009 studies registered for COVID-19 in the ClinicalTrials.gov database (https://clinicaltrials.gov) on August 16, 2020, only $66(\sim 2.2 \%)$ included pregnant women, of which only 6 had been completed, 1 had been withdrawn, and 20 were not yet recruiting.

Specifically in Brazil, the high rates of maternal deaths related to COVID-19 might be associated with poor quality in prenatal and obstetric care. Indeed, SARS-CoV-2 may be an aggravating agent of a previous inflammatory status present in hypertensive disease and/or obesity, which are very prevalent in the country. However, social risks and limited access to health care are probably associated to late proper care, potentially contributing to maternal deaths. ${ }^{69}$

Finally, childbirth care under COVID-19 is still one of the main concerning aspects. However, it is worth observing that, to date, there is no evidence of the intrapartum transmission of SARS-CoV-2 to the newborn, and vaginal birth with appropriate precaution measures remains the mode of delivery in mild maternal disease. Moreover, it is essential to reinforce that interventions to shorten the lenght of the second stage of labor and/or to avoid delayed umbilical cord clamping and/or skinto-skin contact are not supported by good evidence, as well as COVID-19 alone is not an indication for cesarean section. Instead, high rates of cesarean deliveries under COVID-19 are concerning, since they have the potential to promote clinical maternal deterioration. ${ }^{70}$

\section{Fetal and/or Newborn Health}

The effects of viremia on the embryo and/or the fetus in the first and second trimesters of pregnancy are poorly known. Actually, women who became pregnant just before or just after the beginning of the pandemic have not yet delivered their babies; therefore, information from the main pregnancy outcomes is still lacking. With regard to neonates, perhaps the great prospect for the future is the clarification of the causes of prematurity. To date, no one can determine if the higher rates of preterm birth under COVID-19 are spontaneous or elective due to maternal clinical complications or fetal compromise. As a matter of fact, it is not known whether children born to mothers infected by the SARS-CoV-2 will have the same clinical evolution as those born to healthy mothers. And such an answer is totally dependent on time.

\section{Availability and Reliability of Diagnostic Tests}

COVID-19 screening in early pregnancy has been proposed as strategy to better plan maternal-fetal health surveillance programs in epidemic areas, combining serological tests and nucleic acid testing, ${ }^{71}$ mainly for those women presenting for delivery. Those who defend universal screening for parturient women do so based on the benefits of determining hospital isolation practices and bed assignments, informing the neonatal care team, and guiding the use of personal protective equipment. $^{72}$ In contrast, the observation of 3,963 women admitted to labor and delivery in California, United States, resulted in a very low prevalence of positive SARS-CoV-2 testing, ${ }^{73}$ raising doubts about the benefit of mass testing, 
especially in countries like Brazil, in which the testing of large populations still does not seem to be a reality.

\section{Vaccination}

There is no doubt that scientific community is watching a race to launch a vaccine against SRAS-CoV-2. There is also no doubt that, with the first vaccine approved in a phase-III study, we will see one of the fastest, if not the fastest, launches of a vaccine in the entire history of active immunization. But there are questions that will be answered only over time: how effective will the vaccine be? Will there be enough distribution to interrupt or, at least, slow the spread of the virus? How safe will vaccinated women be to decide to become pregnant with the virus still spreading? And, finally, since the immune responses to vaccination in pregnant women may not be the same as those observed in nonpregnant women, ${ }^{74}$ how will the safety of vaccination in pregnancy will be assessed?

\section{Conclusion}

Health professionals and society as a whole have doubts about the impact of COVID-19 on reproductive outcomes, from the impact of SARS-CoV-2 in the gonads and/or gametes to its consequences to the newborn. Data regarding COVID-19 during pregnancy, as it happens with any other pathological condition, are uncertain, possibly due to missingness of pregnancy status, underreporting of cases and disease outcomes, inadequate collection of biological samples for testing, insufficient accuracy of the tests available, and inaccuracy of the mathematical models in predicting the number of asymptomatic individuals. Good quality data are urgently needed to support an adequate counseling to women attempting pregnancy and to those who are already pregnant. With limited evidence available to date, concerning uncertainties from conception to birth inevitably raise the possibility of postponing pregnancy, if possible, to a post-Covid-19 scenario or the one with an effective and broadly-distributed vaccine.

Conflicts to Interest

The authors have no conflict of interests to declare.

\section{References}

1 World Health Organization. Pneumonia of unknown cause China [Internet]. 2020 [cited 2020 Jul 21]. Available from: https://www.who.int/csr/don/05-january-2020-pneumonia-ofunkown-cause-china/en/

2 World Health Organization. Coronavirus disease (COVID-19): situation report - 209 [Internet]. 2020 [cited 2020 Aug 21]. Available from: https://apps.who.int/iris/handle/10665/33 3897

3 Ministério da Saúde. COVID-19 no Brasil [Internet]. 2020 [cited 2020 Aug 16]. Available from: https://susanalitico.saude.gov.br/ extensions/covid-19_html/covid-19_html.html\#/dashboard/

4 Chen H, Guo J, Wang C, Luo F, Yu X, Zhang W, et al. Clinical characteristics and intrauterine vertical transmission potential of COVID-19 infection in nine pregnant women: a retrospective review of medical records. Lancet. 2020;395(10226):809-815. Doi: 10.1016/S0140-6736(20)30360-3
5 Liu D, Li L, Wu X, Zheng D, Wang J, Yang L, Zheng C. Pregnancy and perinatal outcomes of women with Coronavirus Disease (COVID19) pneumonia: a preliminary analysis. AJR Am J Roentgenol. 2020;215(01):127-132. Doi: 10.2214/AJR.20.23072

6 Yu N, Li W, Kang Q Xiong Z, Wang S, Lin X, et al. Clinical features and obstetric and neonatal outcomes of pregnant patients with COVID-19 in Wuhan, China: a retrospective, single-centre, descriptive study. Lancet Infect Dis. 2020;20(05):559-564. Doi: 10.1016/S1473-3099(20)30176-6

7 Schwartz DA. An analysis of 38 pregnant women with COVID-19, their newborn infants, and maternal-fetal transmission of SARSCoV-2: maternal coronavirus infections and pregnancy outcomes. Arch Pathol Lab Med. 2020;•..;. Doi: 10.5858/arpa.2020-0901-SA [ahead of print]

8 Yu N, Li W, Kang Q, Zeng W, Feng L, Wu J. No SARS-CoV-2 detected in amniotic fluid in mid-pregnancy. Lancet Infect Dis. 2020; $\cdots$ : S1473-3099(20)30320-0. Doi: 10.1016/S1473-3099(20)30320-0 [ahead of print]

9 San-Juan R, Barbero P, Fernández-Ruiz M, López-Medrano F, Lizasoáin M, Hernández-Jiménez $\mathrm{P}$, et al. Incidence and clinical profiles of COVID-19 pneumonia in pregnant women: A singlecentre cohort study from Spain. EClinicalMedicine. 2020; 23:100407. Doi: 10.1016/j.eclinm.2020.100407

10 Takemoto MLS, Menezes MO, Andreucci CB, Nakamura-Pereira M, Amorim MMR, Katz L, Knobel R. The tragedy of COVID-19 in Brazil: 124 maternal deaths and counting. Int J Gynaecol Obstet. 2020;•..;. Doi: 10.1002/ijgo.13300 [ahead of print]

11 Zaigham M, Andersson O. Maternal and perinatal outcomes with COVID-19: A systematic review of 108 pregnancies. Acta Obstet Gynecol Scand. 2020;99(07):823-829. Doi: 10.1111/aogs.13867

12 Ellington S, Strid P, Tong VT, Woodworth K, Galang RR, Zambrano LD, et al. Characteristics of women of reproductive age with laboratory-confirmed SARS-CoV-2 infection by pregnancy status - United States, January 22-June 7, 2020. MMWR Morb Mortal Wkly Rep. 2020;69(25):769-775. Doi: 10.15585/mmwr.mm6925a1

13 Sentilhes L, De Marcillac F, Jouffrieau C, Kuhn P, Thuet V, Hansmann Y, et al. Coronavirus disease 2019 in pregnancy was associated with maternal morbidity and preterm birth. Am J Obstet Gynecol. 2020;**:S0002-9378(20)30639-6. Doi: 10.1016/j.ajog.2020.06.022 [ahead of print]

14 Baud D, Greub G, Favre G, Gengler C, Jaton K, Dubruc E, Pomar L. Second-trimester miscarriage in a pregnant woman with SARSCoV-2 infection. JAMA. 2020;323(21):2198-2200. Doi: 10.1001/ jama.2020.7233

15 Shanes ED, Mithal LB, Otero S, Azad HA, Miller ES, Goldstein JA. Placental Pathology in COVID-19. Am J Clin Pathol. 2020;154(01): 23-32. Doi: 10.1093/ajcp/aqaa089

16 Richtmann R, Torloni MR, Oyamada Otani AR, Levi JE, Tobara MC, Silva CA, et al. Fetal deaths in pregnancies with SARS-CoV-2 infection in Brazil: A case series. Case Rep Womens Health. 2020;27:e00243. Doi: 10.1016/j.crwh.2020.e00243

17 Zeng H, Xu C, Fan J, Tang Y, Deng Q Zhang W, Long X. Antibodies in infants born to mothers with COVID-19 pneumonia. JAMA. 2020; 323(18):1848-1849. Doi: 10.1001/jama.2020.4861

18 Dong L, Tian J, He S, Zhu C, Wang J, Liu C, Yang J. Possible vertical transmission of SARS-CoV-2 from an infected mother to her newborn. JAMA. 2020;323(18):1846-1848. Doi: 10.1001/jama. 2020.4621

19 Vivanti AJ, Vauloup-Fellous C, Prevot S, Zupan V, Suffee C, Do Cao J, Benachi A, De Luca D. Transplacental transmission of SARS-CoV-2 infection. Nat Commun. 2020;11(01):3572. Doi: 10.1038/s41467020-17436-6

20 Patanè L, Morotti D, Giunta MR, Cristina Sigismondi C, Piccoli MG, Frigerio L, et al. Vertical transmission of coronavirus disease 2019: severe acute respiratory syndrome coronavirus 2 RNA on the fetal side of the placenta in pregnancies with coronavirus disease 2019-positive mothers and neonates at birth. Am J Obstet Gynecol MFM. 2020;2(03):100145. Doi: 10.1016/j.ajogmf.2020.100145 
21 Rasmussen SA, Jamieson DJ. Caring for women who are planning a pregnancy, pregnant, or postpartum during the COVID-19 pandemic. JAMA. 2020;324(02):190-191. Doi: 10.1001/jama. 2020.8883

22 Stanley KE, Thomas E, Leaver M, Wells D. Coronavirus disease-19 and fertility: viral host entry protein expression in male and female reproductive tissues. Fertil Steril. 2020;114(01):33-43. Doi: 10.1016/j.fertnstert.2020.05.001

23 Jing Y, Run-Qian L, Hao-Ran W, Hao-Ran C, Ya-Bin L, Yang G, Fei C. Potential influence of COVID-19/ACE2 on the female reproductive system. Mol Hum Reprod. 2020;26(06):367-373. Doi: 10.1093/molehr/gaaa030

24 Chadchan SB, Maurya VK, Popli P, Kommagani R. The SARS-CoV-2 receptor, Angiotensin converting enzyme 2 (ACE2) is required for human endometrial stromal cell decidualization. bioRxiv. 2020: 2020.06.23.168252. Preprint. Doi: 10.1101/2020.06.23.168252

25 Fan C, Li K, Ding Y, Lu WL, Wang J. ACE2 expression in kidney and testis may cause kidney and testis damage after 2019-nCoV infection. Medrxiv. 2020

26 Entezami F, Samama M, Dejucq-Rainsford N, Bujan L. SARS-CoV-2 and human reproduction: An open question. EClinicalMedicine. 2020;25:100473. Doi: 10.1016/j.eclinm.2020.100473

27 Segars J, Katler Q, McQueen DB, Kotlyar A, Glenn T, Knight Z, et al; American Society for Reproductive Medicine Coronavirus/COVID19 Task Force. Prior and novel coronaviruses, Coronavirus Disease 2019 (COVID-19), and human reproduction: what is known? Fertil Steril. 2020;113(06):1140-1149. Doi: 10.1016/j.fertnstert.2020.04.025

28 Xu J, Qi L, Chi X, Yang J, Wei X, Gong E, et al. Orchitis: a complication of severe acute respiratory syndrome (SARS). Biol Reprod. 2006;74 (02):410-416. Doi: 10.1095/biolreprod.105.044776

29 Dutta S, Sengupta P. SARS-CoV-2 and male infertility: possible multifaceted pathology. Reprod Sci. 2020;•..;. Doi: 10.1007/ s43032-020-00261-z [ahead of print]

30 Ding Y, He L, Zhang Q, Huang Z, Che X, Hou J, Wang H, et al. Organ distribution of severe acute respiratory syndrome (SARS) associated coronavirus (SARS-CoV) in SARS patients: implications for pathogenesis and virus transmission pathways. J Pathol. 2004; 203(02):622-630. Doi: 10.1002/path.1560

31 Li D, Jin M, Bao P, Zhao W, Zhang S. Clinical characteristics and results of semen tests among men with Coronavirus Disease 2019. JAMA Netw Open. 2020;3(05):e208292. Doi: 10.1001/jamanetworkopen.2020.8292

32 Paoli D, Pallotti F, Colangelo S, Basilico F, Mazzuti L, Turriziani O, et al. Study of SARS-CoV-2 in semen and urine samples of a volunteer with positive naso-pharyngeal swab. J Endocrinol Invest. 2020;•••;. Doi: 10.1007/s40618-020-01261-1 [ahead of print]

33 Pan F, Xiao X, Guo J, Song Y, Li H, Patel DP, et al. No evidence of severe acute respiratory syndrome-coronavirus 2 in semen of males recovering from coronavirus disease 2019. Fertil Steril. 2020;113(06):1135-1139. Doi: 10.1016/j.fertnstert.2020.04.024

34 Wong SF, Chow KM, Leung TN, Ng WF, Ng TK, Shek CC, et al. Pregnancy and perinatal outcomes of women with severe acute respiratory syndrome. Am J Obstet Gynecol. 2004;191(01): 292-297. Doi: 10.1016/j.ajog.2003.11.019

35 Alfaraj SH, Al-Tawfiq JA, Memish ZA. Middle East Respiratory Syndrome Coronavirus (MERS-CoV) infection during pregnancy: Report of two cases \& review of the literature. J Microbiol Immunol Infect. 2019;52(03):501-503. Doi: 10.1016/j. jmii.2018.04.005

36 Liu H, Wang LL, Zhao SJ, Kwak-Kim J, Mor G, Liao AH. Why are pregnant women susceptible to COVID-19? An immunological viewpoint. J Reprod Immunol. 2020;139:103122. Doi: 10.1016/j. jri.2020.103122

37 Centers for Disease Control and Prevention. Assessing risk factors for severe COVID-19 illness [Internet]. 2020 [cited 2020 Jul 26]. Available from: https://www.cdc.gov/coronavirus/2019-ncov/covid-data/investigations-discovery/assessing-risk-factors.html
38 Trapani Júnior A, Vanhoni LR, Silveira SK, Marcolin AC. Childbirth, puerperium and abortion care protocol during the COVID-19 pandemic. Rev Bras Ginecol Obstet. 2020;42(06):349-355. Doi: $10.1055 / \mathrm{s}-0040-1713587$

39 Lopes de Sousa AF, Carvalho HEF, Oliveira LB, Schneider G, Camargo ELS, Watanabe E, et al. Effects of COVID-19 infection during pregnancy and neonatal prognosis: what is the evidence? Int J Environ Res Public Health. 2020;17(11):E4176. Doi: 10.3390/ ijerph17114176

40 Api O, Sen C, Debska M, Saccone G, D’Antonio F, Volpe N, et al. Clinical management of coronavirus disease 2019 (COVID-19) in pregnancy: recommendations of WAPM-World Association of Perinatal Medicine. J Perinat Med. 2020;•••:/j/jpme.ahead-of-print/jpm-20200265/jpm-2020-0265.xml 10.1515/jpm-2020-0265 [ahead of print]

41 Della Gatta AN, Rizzo R, Pilu G, Simonazzi G. Coronavirus disease 2019 during pregnancy: a systematic review of reported cases. Am J Obstet Gynecol. 2020;223(01):36-41. Doi: 10.1016/j. ajog.2020.04.013

42 Di Mascio D, Khalil A, Saccone G, Rizzo G, Buca D, Liberati M, et al. Outcome of coronavirus spectrum infections (SARS, MERS, COVID-19) during pregnancy: a systematic review and metaanalysis. Am J Obstet Gynecol MFM. 2020;2(02):100107. Doi: 10.1016/j.ajogmf.2020.100107

43 Antoun L, Taweel NE, Ahmed I, Patni S, Honest H. Maternal COVID19 infection, clinical characteristics, pregnancy, and neonatal outcome: A prospective cohort study. Eur J Obstet Gynecol Reprod Biol. 2020;252:559-562. Doi: 10.1016/j.ejogrb.2020.07.008

44 Gagneur A, Dirson E, Audebert S, Vallet S, Quillien MCL, Baron R, et al. Transmission maternofoetale des coronavirus humains. Etude prospective pilote. Pathol Biol (Paris). 2007;55(10): 525-530. Doi: 10.1016/j.patbio.2007.07.013

45 Gagneur A, Dirson E, Audebert S, Vallet S, Legrand-Quillien MC, Laurent $Y$, et al. Materno-fetal transmission of human coronaviruses: a prospective pilot study. Eur J Clin Microbiol Infect Dis. 2008;27(09):863-866. Doi: 10.1007/s10096-008-0505-7

46 Schwartz DA, Graham AL. Potential maternal and infant outcomes from (Wuhan) Coronavirus 2019-nCoV (SARS-CoV-2) infecting pregnant women: lessons from SARS, MERS, and other human Coronavirus infections. Viruses. 2020;12(02):194. Doi: 10.3390/v12020194

47 Liu W, Wang J, Li W, Zhou Z, Liu S, Rong Z. Clinical characteristics of 19 neonates born to mothers with COVID-19. Front Med. 2020; 14(02):193-198. Doi: 10.1007/s11684-020-0772-y

48 Smithgall MC, Liu-Jarin X, Hamele-Bena D, Cimic A, Mourad M, Debelenko L, Chen X. Third-trimester placentas of severe acute respiratory syndrome coronavirus 2 (SARS-CoV-2)-positive women: histomorphology, including viral immunohistochemistry and in-situ hybridization. Histopathology. 2020;0..;. Doi: 10.1111/his.14215 [ahead of print]

49 Alzamora MC, Paredes T, Caceres D, Webb CM, Valdez LM, La Rosa M. Severe COVID-19 during pregnancy and possible vertical transmission. Am J Perinatol. 2020;37(08):861-865. Doi: 10.1055/s-0040-1710050

50 Kirtsman M, Diambomba Y, Poutanen SM, Malinowski AK, Vlachodimitropoulou E, Parks WT, et al. Probable congenital SARS$\mathrm{CoV}-2$ infection in a neonate born to a woman with active SARSCoV-2 infection. CMAJ. 2020;192(24):E647-E650. Doi: 10.1503/ cmaj.200821

51 Zhang ZJ, Yu XJ, Fu T, Liu Y, Jiang Y, Yang BX, Bi Y, et al. Novel coronavirus infection in newborn babies aged $<28$ days in China. Eur Respir J. 2020;55(06):2000697. Doi: 10.1183/13993003.006972020

52 Hu X, Gao J, Luo X, Feng L, Liu W, Chen J, et al. Severe Acute Respiratory Syndrome Coronavirus 2 (SARS-CoV-2) vertical transmission in neonates born to mothers with Coronavirus Disease 2019 (COVID-19) pneumonia. Obstet Gynecol. 2020; 136(01):65-67. Doi: 10.1097/AOG.0000000000003926

53 Maternal-fetal vertical SARS-CoV2 transmission cannot be dismissed. ESHRE Annual Meeting 2020 [cited 2020 Jul 26]. Available 
from: https://www.focusonreproduction.eu/article/ESHRE-NewsAnnual-Meeting-2020-Bahadur

54 Li M, Chen L, Zhang J, Xiong C, Li X. The SARS-CoV-2 receptor ACE2 expression of maternal-fetal interface and fetal organs by singlecell transcriptome study. PLoS One. 2020;15(04):e0230295. Doi: 10.1371/journal.pone.0230295

55 Freiesleben NLC, Egerup P, Hviid KVR, Severinsen ER, Kolte AM, Westergaard D, et al. SARS-CoV-2 in first trimester pregnancy does it affect the fetus? Medrxiv. 2020

56 Moore CA, Staples JE, Dobyns WB, Pessoa A, Ventura CV, Fonseca $\mathrm{EB}$, et al. Characterizing the pattern of anomalies in congenital Zika syndrome for pediatric clinicians. JAMA Pediatr. 2017;171 (03):288-295. Doi: 10.1001/jamapediatrics.2016.3982

57 Penfield CA, Brubaker SG, Limaye MA, Lighter J, Ratner AJ, Thomas $\mathrm{KM}$, et al. Detection of severe acute respiratory syndrome coronavirus 2 in placental and fetal membrane samples. Am J Obstet Gynecol MFM. 2020;2(03):100133. Doi: 10.1016/j.ajogmf.2020.100133

58 Walker KF, O’Donoghue K, Grace N, Dorling J, Comeau JL, Li W, Thornton JG. Maternal transmission of SARS-COV-2 to the neonate, and possible routes for such transmission: a systematic review and critical analysis. BJOG. 2020;127(11):1324-1336. Doi: 10.1111/1471-0528.16362

59 Philip RK, Purtill H, Reidy E, et al. Reduction in preterm births during the COVID-19 lockdown in Ireland: a natural experiment allowing analysis of data from the prior two decades. Medrxiv. 2020

60 Hedermann G, Hedley PL, Bækvad-Hansen M, Hjalgrim H, Rostgaard K, Poorisrisak P, et al. Danish premature birth rates during the COVID-19 lockdown. Arch Dis Child Fetal Neonatal Ed. 2020: fetalneonatal-2020-319990

61 Lobo RA. Potential options for preservation of fertility in women. N Engl J Med. 2005;353(01):64-73. Doi: 10.1056/NEJMra043475

62 Heffner LJ. Advanced maternal age-how old is too old? N Engl J Med. 2004;351(19):1927-1929. Doi: 10.1056/NEJMp048087

63 Habbema JD, Eijkemans MJ, Leridon H, te Velde ER. Realizing a desired family size: when should couples start? Hum Reprod. 2015;30(09):2215-2221. Doi: 10.1093/humrep/dev148

64 Eijkemans MJC, Kersten FAM, Lintsen AME, Hunault CC, Bouwmans CAM, Hakkaart-van-Roijen L, et al. Cost-effectiveness of 'immediate IVF' versus 'delayed IVF': a prospective study. Hum Reprod. 2017;32(05):999-1008. Doi: 10.1093/humrep/dex018
65 Romanski PA, Bortoletto P, Rosenwaks Z, Schattman GL. Delay in IVF treatment up to 180 days does not affect pregnancy outcomes in women with diminished ovarian reserve. Hum Reprod. 2020; 35(07):1630-1636. Doi: 10.1093/humrep/deaa137

66 Carvalho BR, Rosa-E-Silva ACJS, Ferriani RA, Reis RMD, Silva de Sá MF. COVID-19 and assisted reproduction: a point of view on the Brazilian scenario. Rev Bras Ginecol Obstet. 2020;42(06): 305-309. Doi: 10.1055/s-0040-1713795

67 Papathanasiou A. COVID-19 screening during fertility treatment: how do guidelines compare against each other? J Assist Reprod Genet. 2020;37(08):1831-1835. Doi: 10.1007/s10815-02001885-5

68 Oxford-Horrey C, Savage M, Prabhu M, Abramovitz S, Griffin K, LaFond E, et al. Putting it all together: clinical considerations in the care of critically ill obstetric patients with COVID-19. Am J Perinatol. 2020;37(10):1044-1051. Doi: 10.1055/s-0040-1713121

69 Takemoto M, Menezes MO, Andreucci CB, Knobel R, Sousa L, Katz L, et al;Brazilian Group for Studies of COVID-19 and Pregnancy. Clinical characteristics and risk factors for mortality in obstetric patients with severe COVID-19 in Brazil: a surveillance database analysis. BJOG. 2020;•••;. Doi: 10.1111/1471-0528.16470 [ahead of print]

70 Martínez-Perez O, Vouga M, Cruz Melguizo S, Acebal LF, Panchaud A, Muñoz-Chápuli M, Baud D, et al. Association between mode of delivery among pregnant women with covid-19 and maternal and neonatal outcomes in Spain. JAMA. 2020;324(03):296-299. Doi: $10.1001 /$ jama.2020.10125

71 Cosma S, Borella F, Carosso A, Sciarrone A, Cusato J, Corcione S, et al. The "scar" of a pandemic: Cumulative incidence of COVID-19 during the first trimester of pregnancy. J Med Virol. 2020;•••;. Doi: 10.1002/jmv.26267 [ahead of print]

72 Sutton D, Fuchs K, D’Alton M, Goffman D. Universal screening for SARS-CoV-2 in women admitted for delivery. N Engl J Med. 2020; 382(22):2163-2164. Doi: 10.1056/NEJMc2009316

73 Fassett MJ, Lurvey LD, Yasumura L, Nguyen M, Colli JJ, Volodarskiy $\mathrm{M}$, et al. Universal SARS-Cov-2 screening in women admitted for delivery in a large managed care organization. Am J Perinatol. 2020;37(11):1110-1114. Doi: 10.1055/s-0040-1714060

74 Heath PT, Le Doare K, Khalil A. Inclusion of pregnant women in COVID-19 vaccine development. Lancet Infect Dis. 2020;20(09): 1007-1008. Doi: 10.1016/S1473-3099(20)30638-1 